\title{
Ginter Dzierżon
}

\section{Aplikacja kategorii aktu prawnego w kanonicznym prawie małżeńskim}

Ius Matrimoniale 5 (11), 9-21

2000

Artykuł został zdigitalizowany i opracowany do udostępnienia w internecie przez Muzeum Historii Polski w ramach prac podejmowanych na rzecz zapewnienia otwartego, powszechnego i trwałego dostępu do polskiego dorobku naukowego i kulturalnego. Artykuł jest umieszczony w kolekcji cyfrowej bazhum.muzhp.pl, gromadzącej zawartość polskich czasopism humanistycznych i społecznych.

Tekst jest udostępniony do wykorzystania w ramach dozwolonego użytku. 


\section{ROZPRAWY I ARTYKUEY}

Ius Matrimoniale 5 (11) 2000

ks. Ginter Dzierżon

\section{Aplikacja kategorii aktu prawnego w kanonicznym prawie malżeńskim}

Małżeństwo jako instytucja jurydyczna jest na pewno rzeczywistością bardzo bogata. Stąd też badania nad materialnym prawem małżeńskim można przeprowadzić z różnych aspektów. W tym kontekście bardzo interesującym wydaje się być ujęcie tego zjawiska prawnego z perspektywy ogólnej teorii aktu prawnego. Punktem wyjścia w prezentacji tego zagadnienia stanie się próba zdefiniowania kategorii aktu prawnego oraz odróżnienia tej figury od zjawisk jej pokrewnych. Dysponując tak sprecyzowaną kategorią jurydyczną, będziemy starali się odpowiedzieć na pytanie: czy można mówić o jej aplikacji w kanonicznym prawie małżeńskim?

\section{Definicja oraz natura aktu prawnego}

Rozpoczynając analizę prezentowanego zagadnienia na pozór mogłoby się wydawać, iż w systemach prawnych już w dalekiej przeszłości zostało sprecyzowane pojęcie aktu prawnego. Tak jednak nie było. Prawnicy bowiem w myśl zasady, iż omnis definitio in iure periculosa est unikali formułowania definicji. Tak było między innymi w systemie prawa rzymskiego. W tymże porządku jurydycznym funkcjonowało między innymi zjawisko actus iuridicus. Rzymscy iurisprudentes w tym fenomenie wyszczególniali jego istotne elementy, a mianowicie: akt woli ( $v o-$ luntarietas), skutek prawny (effectus iuridicus) oraz prawo obiektywne (ius obiectivum)'. Jednak należy dodać, iż brak było nie tylko definicji

\footnotetext{
${ }^{1}$ Zob. O. Robleda, De conceptu actus iuridici, Periodica 51: 1962, s. 414.
} 
legalnych, lecz także wypracowanej przez doktrynę ogólnej teorii aktu prawnego ${ }^{2}$.

Na pierwszą definicję trzeba jednak było czekać aż do XVIII w. kiedy to Nettelbladt, należący do szkoły Wollffianama, sprecyzował tę kategorię jurydyczną ${ }^{3}$. Stwierdzil on bowiem, iż ,, actus iuridicus dicitur qui iura et obligationes concernit" "4. W tym twierdzeniu uwydatnił on walor elementu podmiotowego. Teoretycy prawa w XX wieku pogłębiając rozumienie tej kategorii prawnej, z jednej strony akcentowali wartość wolności człowieka; z drugiej zaś strony podkreślali znaczenie porządku prawnego ${ }^{5}$.

Analizując rozwój tego zagadnienia w obszarze prawa kanonicznego należy zauważyć, iż w doktrynie przedkodeksowej nie wypracowano ogólnej teorii aktu prawnego ${ }^{6}$. Sformułowania kan. $103-104 \mathrm{kpk}$ z 1917 r. stały się pierwszymi regulacjami prawnymi w tym zakresie. W tym miejscu należy jednocześnie zaznaczyć, iż prawodawca zarówno w Kodeksie z 1917 r. jak również w Kodeksie z 1983 r. nie sformułował definicji actus iuridicus (kan. 124 - $128 \mathrm{kpk}$ z 1983 r.).

Wspomniane regulacje prawne Kodeksu pio - benedyktyńskiego stały się dla kanonistów zachętą do podjęcia badań w tej dziedzinie, a w konsekwencji przyczyniły się do wypracowania kanonistycznej teorii aktu prawnego. Klasycznymi już dziś są definicje wypracowane przez O. Robledę czy też G. Michielsa. Zdaniem tego pierwszego actus iuridicus jest aktem woli wyrażonym w sferze zewnętrznej, wywołujący ściśle określony skutek prawny ${ }^{7}$. G. Michiels natomiast jeszcze precyzyjniej

\footnotetext{
${ }^{2}$ Zob. A. Burdese, Atti delle persone: i vizi dell'atto giuridico in diritto romano, w: Atti del Colloquio romanistico - canonistico (febbraio 1978), Roma 1979, s. 235. Autor ten stwierdzil: „(...) manca da parte del pensicro giuridico in tutte le fasi della sua milenaria evoluzione storica, l'elaborazione di una teoria generale dell'atto giuridico (...)".

${ }^{3}$ Robleda, De conceptu, j.w., s. 414; M. Walser, Die Rechtshandlung in kanonischen Recht. Ihre Gültigkeit und Ungültigkeit gemäß dem Codex Iuris Canonici, Göttingen 1994, s. 8.

${ }^{4}$ Zob. W. Flum, Das Rechtsgeschäft, w: Enzyklopädic der Rechts - und Staatswissenschaft, t. 2, Berlin-Heidelberg-New York 1965, s. 29; Walser, j.w.,; s. 8.

${ }^{5}$ Tamże, s. 9.

' Zob. S. Romani, De factis actibus negotiisque juridicis, Ius Ponficium 18: 1938, s. 101 102.

${ }^{7}$ O. Robleda, De conceptu, j.w., s. 419. Kanonista ten stwierdził: „(...) pro actu iuridico intelligimus voluntatis actum externe manifestatum quo certus effectus iuridicus intenditur". Definicja zaprezentwana może suponować równicż, iż pojęcie certus effectus iuridicus oznacza „pewien skutek prawny". Tak jednak tego pojęcia nie należy rozumieć. Kontekst bowiem całego artykułu wskazuje, iż idzie o ,ściślc określony skutek prawny". Podobną definicję przedstawił A. Schönegger. Zob. A. Schönegger, Canonis $105 \mathrm{n}$. I interpretatio et interpretes, Periodica 31: 1942, s. 121: "Agere iuridice est ponere actum voluntatis, ut sequatur effectus iuridicus".
} 
uwydatnił mechanizmy działania tejże figury prawnej. Pod tym pojęciem rozumiał on bowiem akt ludzki o naturze społecznej, wyrażony zgodnie z prawem, którego konsekwencje zamierzone przez działającego zostały ściśle zdeterminowane przez prawodawcę ${ }^{8}$. W tym miejscu należy zauważyć, iż do tych ujęć nawiązują również i współcześni kanoniści, a mianowicie J. Fornés ${ }^{9}$, L. Vela ${ }^{10}$, J. Castano ${ }^{11}$, J. García Faílde ${ }^{12}$, czy też García Martín ${ }^{13}$.

W analizie natury tego zjawiska nie trudno zauważyć, iż jego fundamentem jest akt ludzki (actus humanus) wyrażony w sferze społecznej, tzn. w sferze zewnętrznej. Stąd też dla zaistnienia actus iuridicus nie wystarcza wola wewnętrzna ${ }^{14}$. Pojęcie zaś ,,zgodnie z prawem" (legitime positus) wskazuje, iż tenże akt powinien odpowiadać wszystkim wymaganiom stawianym przez ustawodawcę ${ }^{15}$. $Z$ drugiej strony należy podkreślić, iż musi istnieć ścisła korelacja pomiędzy zamiarem podmiotu działającego co do osiągnięcia określonych skutków prawnych, a implikacjami określonymi przez legislatora. Stąd też w odniesieniu do tej figury prawnej nie można mówić o autonomii prywatnej danej osoby ${ }^{16}$.

W myśl opinii teoretyków prawa idzie o kategorię aktu dozwolonego (actus iuridicus licitus). W tym przypadku bowiem intencja podmiotu

\footnotetext{
${ }^{8}$ Zob. G. Michiels, Principia generalia de personis in Ecclesia. Commentarius libri II Codicis juris canonici. Canones praeliminares, Parisiis-Tornaci-Romae 1955, s. 572: „Actus humanus socialis legitime positus et declaratus, cui a lege ideo et eatenus effectus juridicos determinatos agnoscitur, quia et quatenus effectus ille ab agente intenditur".

${ }^{9}$ Zob. J. Fornés, El acto jurídico-canonico (sugerencias para una teoría general), Ius Canonicum 25: 1985, s. 72. Czytamy tutaj: „Acto humano social, legitimamente realizado y declarado, al que la ley reconoce un cfecto juridico determinado, en tanto en cuanto a quel efecto es buscado o pretendido por $\mathrm{cl}$ agente".

${ }^{10}$ Zob. L. Vela, Atto giuridico (Actus iuridicus), w: Nuovo Dizionario di Diritto Canonico, pod red. C. Coral Salvador, V. De Paolis, G. Ghirlanda, Ciniselo Balsamo 1993, s. 66: „Atto giuridico è un atto della volontà diretto a produrre determinati effetti giuridici. È un atto umano, atto deliberato proprio della persona razionalc. E un atto intenzionale".

${ }^{11}$ Zob. J. Castano, I vizi dell'atto giuridico in diritto canonico, Apollinaris 51 - 1978, s. 595.

${ }^{12}$ Zob. J. García Faílde, Inexistencia o ineficacia del consentimiento, w: Curso de derecho matrimonial y procesal para profesionales del foro, pod red. J. Sanchez y Sanchez, t. 5, Salamanca 1982, s. 93: ,(..) pro actu juridico intelligimus voluntatis actum externe manifestatum quo certus effectus juridicus intenditur".

${ }^{13}$ Zob. J. Garcia Martín, Le norme generali del Codex Iuris Canonici, Roma 1995, s. 389

${ }^{14}$ Zob. O. Robleda, La nulídad del acto jurídico, Roma 1964, s. 7 i 14 : „El atributo externo, por tanto, aplicado al acto juridico se ha de entender en el sentido de que el acto pueda ser apreciado socialmente"; Michicls, j.w., s. 372.

${ }^{15}$ Tamże.

${ }^{16}$ Tamże, s. 373.
} 
jest zgodna $z$ prawem, tzn. jest koherentna $z$ wolą prawodawcy. W kanonistycznym porządku prawnym tę figurę należy jednak odróżnić od pojęcia aktu prawnego niedozwolonego (actus iuridicus illicitus). Albowiem w sferze zachowań ludzkich mogą przecież wystąpić działania przeciwne prawu, co do których prawodawca przewidział sankcje ${ }^{17}$.

\section{Figury pokrewne aktowi prawnemu}

Analizując strukturę systemów prawnych należy zauważyć, iż występują w nich również figury zbliżone do zjawiska aktu prawnego. Do nich należy zaliczyć następujące kategorie, a mianowicie: fakty prawne, działania prawne oraz inne akty.

\subsection{Fakt prawny}

W przestrzeni jurydycznej obok fenomenu aktu prawnego występuje również zjawisko faktu prawnego (factum iuridicum). Pod tym pojęciem rozumie się wydarzenia rodzące, zmieniające lub znoszące sytu-

${ }^{17}$ Vela, j.w., s. 66: „L'atto illecito è l'atto volontario contrario al diritto, è la libera decisione della volontŕ a favore di una condotta antigiuridica, malgrado sia o debba essere stata riconosciuta l'antigiuridicità. In questi atti la volontà è diretta ad effetti meramente pratici ed è solo un presupposto affinchè non da essa, bensí dal diritto, seguano gli effetti giuridici sanzionanti.

È essenziale insistere che è la volontà privata, come esige il diritto naturale, la causa efficiente principale degli effetti giuridici, e non la norma giuridica che li riconosce. Accentuando cosi tanto l'aspetto privato dell'atto giuridico, non vogliamo escludere l'aspetto pubblico, giacchè le persone pubbliche, tanto nella funzione legislativa come in quella giudiziale e amministrativa, esercitano la loro attività per mezzo di atti giuridici strettamenti tali, cioè nei quali la volontá è ordinata a produrre effetti giuridici'; H. Pree, Allgemeine Normen: Rechtshandlungen, w: Münsterischer Kommentar zum Codex Iuris Canonici, t. 1, Essen 1985, Einführung vor $124 \mathrm{nr} 3$ : „Aus inhaltlich-systematischen Gesichtspunkten ergibt sich in negativer Hinsicht, daß actus iuridici nicht unerlaubte Handlungen (actus illiciti) als solche, insbesondere nicht strafrechtliche Delikte. Bei den uncrlaubten Akten ist der Handlungswille nicht auf die Rechtsverletzung bzw. die Herbeifuihrung der von der Rechtsordnung dafür vorgesehenen Sanktion gerichtet, sondern auf den äußeren, faktischen Erfolg. Deshalb sind die actus illiciti grundsätzlich so wie die facta iuridica zu behandeln: Von den actus illiciti im Sinne von rein schädigenden bzw. rechtsverletzenden Handlungen sind die actus iuridici illiciti bzw. prohibiti (z.B. eine entgegen dem Verbot des 1124 geschlossene Mischche) strikt zu unterscheiden. Bei letzteren liegt ein gültiger Rechtsakt vor, der lediglich aufgrund der äußeren Umstände, unter denen er gesetzt wird, unter Sanktion gestellt wird (Verbot, Schadenersatzpflicht, Strafdrohung)"; O. Robleda, De conceptu, j.w., s. 419-420; Tenże, La nulidad, j.w., s. 18-20. 
ację prawną ${ }^{18}$. Należy jednocześnie zauważyć, iż funkcjonowanie tej kategorii jurydycznej jest odmienne od mechanizmów działania aktu prawnego. Dany fakt wywiera bowiem konsekwencje prawne nie dlatego, iż pragnął tego dany podmiot. Dzieje się tak, ponieważ chce tego prawodawca. On to bowiem określa skutki prawne w odniesieniu do danego wydarzenia. Stąd też fakt pojmowany sam w sobie nie rodzi żadnych konsekwencji prawnych, lecz staje się on jedynie okazją lub jedną z przyczyn powodujących określone konsekwencje jurydyczne ${ }^{19}$.

Prezentowane zjawisko może wystąić niezależnie od woli człowieka, jak również może być zależne od decyzji danego indywiduum. Dlatego też można mówić o faktach prawnych niezależnych od woli człowieka (factum iuridicum involuntarium) oraz faktach prawnych zależnych od woli podmiotu (factum iuridicum voluntarium) ${ }^{20}$.

W przypadku factum iuridicum involuntarium idzie o wydarzenia niezależne od woli człowieka, któremu to jednak prawodawca przypisał

${ }^{18}$ Zob. P. Ciprotti, Lezioni di diritto canonico. Parte generale, Padova 1943, s. 136: ,(...) meglio potremo definire il fatto giuridico, come quel fatto, che produce la nascita, il mutamento o l'estinzione di una situazione giuridica"; Tenże, Atto giuridico, w: Enciclopedia del diritto, t. 4, Varese 1959, 138-144; Michiels, j.w., s. 368; Walser, j.w., s. 13; W. Aymans: Aymans - Mörsdorf, Kanonisches Recht. Lehrbuch aufgrund des Codex Iuris Canonici. Begründet von E. Eichmann, fortgeführt von Klaus Mörsdorf, neu bearbeitet von W. Aymans, t. 1, Paderborn - MünchenZürich 1991, s. 202; H. Heimler, H. Pree, Kirchenrecht. Allgemeine Normen und Eherecht, Wien New York 1983, s. 101-102; Hilling, Die Allgemeinen Normen des Codex Iuris Canonici, Freiburg 1926, s. 118-120. Na marginesie należy dodać, iż niektórzy teoretycy prawa zaliczają pojęcic faktu prawnego do kategorii aktu prawnego. Np. N. Hilling. Zob. N. Hilling, Die fehlerhaften Rechtshandlungen und ihre Heilung, Archiv für katholisches Kirchenrecht 107: 1927, s. 7.

${ }^{19}$ Ciprotti, Lezioni, j.w., s. 136: „Occorre però, per aver ben chiara tale nozione, avvertire, che tali effetti (giuridici) possono aversi solo in quanto preesista un comando giuridico, il quale dall'accadere di quel fatto li faccia derivare: in quanto cioè il fatto (empirico o materiale) rientri nella fattispecie di un comando giuridico.

E perciò non si deve intendere il fatto giuridico come la causa degli effetti giuridici, ma piuttosto come l'occasione, o come una delle cause, tanto più che derivando dalla maggior parte dei fattii giuridici il mutamento o l'estinzione di situazioni giuridice, anzichè la sola nascita, anche la situazione che viene mutata o estinta si trova, di fronte agli effetti giuridici, in posizione analoga a quella in cui si trova il fatto".

${ }^{20}$ Robleda, De conceptu, j.w., s. 421; Tenże, La nulidad, j.w., s. 17; Michiels, j.w., s. 595; Castano, j.w., s. 252-253; V. Del Giudice, Nozioni di diritto canonico, Milano 1970, s. 70; V. de Paolis, A. Montan, Il libro I del Codice: norme generali (can. 1-203), w: Il diritto nel mistero della Chiesa, t. 1, Roma 1988, s. 361. Taka systematyzacja wydaje się być wystarczająca w ramach niniejszego opracowania. Szerzej na temat typologii tego zjawiska prawnego zob. C. Malorca, Fatto giurdico - fattispecie, w: Novissimo digesto italiano, pod red. E. Eula, A. Azara, t. 7, Torino 1961, s. 113-138. 
określone efekty prawne (efecti iuridici) ${ }^{21}$. Faktami tego rodzaju w kanonistycznym systemie prawnym są między innymi prawe lub nieprawe pochodzenie dziecka, czy też śmierć człowieka.

Większość jednak ludzkich zachowań wiąże się z wydarzeniami zależnymi od decyzji danej jednostki, jako autora. W tym przypadku mamy na myśli akty woli danego podmiotu pociągające za sobą określone konsekwencje jurydyczne. Te ostatnie nie wynikająjednak z żadnego paktu, lecz są stanowione prawem pozytywnym ${ }^{22}$. Część teoretyków prawa utożsamia to zjawisko prawne $z$ kategorią aktu prawnego ${ }^{23}$. Niezupelnie jednak można się zgodzić z tymi opiniami, bowiem pomiędzy actus iuridicus oraz factum iuridicum zachodzą subtelne różnice, wiążące się z odmiennymi mechanizmami funkcjonowania tych fenomenów prawnych. Ich odmienność należy dostrzec przede wszystkim w sferze wolitywnej danego podmiotu. W przypadku faktu prawnego dana osoba nie chce bezpośrednio osiagnięcia skutku prawnego określonego w danym systemie prawnym; pragnie jedynie skutku praktycznego. Wywołany skutek jest jednak zgodny z wolą ustawodawcy, tzn. powoduje również konsekwencje prawne ${ }^{24}$. Tak więc w sposobie funkcjonowania tej kategorii jurydycznej nie zachodzi bezpośrednia korelacja pomiędzy woląjednostki a konsekwencjami jurydycznymi zdeterminowanymi przez ustawodawcę. Istnieje natomiast związek przyczynowy pomiędzy danym faktem a zamiarem prawodawcy. Stąd też w odniesieniu do factum iuridicum, jego skutki jurydyczne określa prawo pozytywne. W przypadku zaś actus iuridicus, jak wspomniano już wyżej, to właśnie wola danego indy-

\footnotetext{
${ }^{21}$ Robleda, De conceptu, j.w., s. 419: Autor ten stwierdził: ,(..) in hoc nullo modo intervenit voluntas, sed agitur de aliquo eventu cursus necesarii naturae, cui ordo iuris obiectivi, seu Societas organizata, aut si vis, legislator, effectum vel effectus iuridicos vinculat"; Castano, j.w., s. 595; W. Onclin, De requsitis ad actus iuridici existentiam ad validitatem, w: Studi in onore di Pietro D'Avack, t. 3, Milano 1976, s. 399; Vela, j.w., s. 66; Pree, j.w., Einführung vor 124 nr 3.

22 Robleda, De conceptu, j.w., s. 421. Czytamy tutaj: "Distinguitur tandem facta iuridica voluntaria (licita). In his factum pendet ab homine, non a natura, hebetque effectum iuridicum, certe, non contrarium voluntati, at non quesitum $a b c a$, unde nec ab ullo pacto productum, sed a lege positiva".

${ }^{23}$ Castano, j.w., s. 595: „, (...) i «facta iuridica voluntaria» sono quelli che procedono della libera volontà dell'uomo $\mathrm{e}$ che hanno valore giuriciico in forza della stessa legge, cioè producono effetti giuridici perché, secondo la legge, sono «facta voluntaria». Questi «facta voluntaria» vengono chiamati con un termine proprio, sono cioè «acta iuridica» veri e propri"; Ciprotti, Lezioni, j.w., s. 138.

${ }^{24}$ Robleda, De conceptu, j.w., s. 426: „Sic, ergo distinximus actum iuridicum a facto iuridico hominis: praecise quia agens vel operans non querit in hoc effectum iuridicum, sed pure practicum, potest ignorare".
} 
widuum staje się causa efficiens skutku prawnego, skądinąd ściśle sprecyzowanego przez legislatora. Tak więc mamy tutaj do czynienia z synchronizacją zamiarów podmiotu oraz wymogów prawodawcy ${ }^{25}$.

W tym miejscu należy także zauważyć, iż w myśl opinii niektórych teoretyków prawa, w kanonistycznym porządku prawnym spotykamy się również $\mathrm{z}$ kategorią faktów mieszanych. Ich zdaniem zjawisko to ma miejsce $\mathrm{w}$ czasie przyjmowania sakramentów św. Zamiar ich przyjęcia zależy zasadniczo, choć nie zawsze, od decyzji człowieka ${ }^{26}$, lecz ich skutek jest zależny od rzeczywistości ponadnaturalnejej ${ }^{27}$.

\subsection{Dzialanie prawne}

Analizując kwestie relacji actus iuridicus do figur mu pokrewnych należy jeszcze przedstawić jego odniesienie do kategorii działania prawnego (negotium iuridicum). Rozróżnienie pomiędzy tymi zjawiskami wprowadził B. Windscheid ${ }^{28}$. Figura negotium iuridicum funkcjonuje szczególnie w systemach cywilistycznych (np. w prawodawstwie włoskim nazywa się ją il negozio giuridico; w ustawodawstwie niemieckim określa się ją mianem das Rechtsgeschäft).

W tym miejscu należy podkreślić, iż w kanonistycznym porządku prawnym dominuje zjawisko aktu prawnego. O. Robleda, wybitny znawca tego zagadnienia, uważa stosowanie tej ostatniej kategorii w prawie kanonicznym za bardziej korzystne. Według niego, za przyjęciem tej hipotezy przemawiają następujące przesłanki: a) pojęcie to występuje w źródłach; b) bardziej przekonywujące jest stosowanie tej kategorii w odniesieniu do prawa publicznego, a co za tym idzie odpowiada ona naturze prawa kanonicznego ${ }^{29}$.

${ }^{25}$ Tamże, s. 427: „(...) si necessaria foret directio voluntatis in effectus iuridicos haberetur voluntas ut causa eorum, cum revera causa effectum iuridicorum non voluntas, sed ius obiectivum positivum sit"; O. Robleda, La nulidad, j.w., s. 17.

${ }_{20}^{20}$ Taki mechanizm prawny jednak nic zawsze jest reguła. Można się bowiem spotkać z sytuacjami, w których ważność skuteczność sakramentu nie jest zależna od woli przyjmującego, np. chrzest dzieci, namaszczenie chorych pozbawionych świadomości. Szafarz sakramentu musi być jednak przekonany przynajmniej o istnieniu odpowiednicj woli habitualnej u przyjmującego.

${ }^{27}$ Aymans, j.w., s. 331; Walser, j.w., s. $14-15$.

${ }^{28}$ Zob. B. Windscheid, Diritto delle Pandette, Torino 1925, s. 202. W myśl opinii O. Robledy sformułowal on następującą definicję tego zjawiska prawnego, a mianowicie: „Negozio giuridico è una dichiarazione privata di volontà, che mira a produrre un effetto giuridico".

${ }^{29}$ Robleda, De conceptu, j.w., s. 418 ; Walser, j.w., s. 9. 
Na marginesie należy jednak zauważyć, iż teoretycy prawa cywilnego prowadzą ożywioną dyskusję co do rozumienia natury działania prawnego ${ }^{30}$. Najogólniej rzecz ujmując, pod pojęciem negotium iuridicum rozumie się akt woli, w którym podmiot działania pragnie osiągnąć skutek prawny zamierzony przez siebie. Tak więc w mechanizmach działania tej figury prawne modyfikacje sytuacji jurydycznych są uzależnione wyłącznie od decyzji danego podmiotu ${ }^{31}$. Stąd też pomiędzy aktem prawnym a działaniem prawnym zachodzą różnice zarówno strukturalne jak i funkcjonalne ${ }^{32}$. Fundamentem funkcjonowania tego ostatniego zjawiska jest bowiem zasada autonomii prywatnej. W przypadku bowiem zaistnienia tego fenomenu następuje realizacja praw podmiotowych ${ }^{33}$. Natomiast $w$ akcie prawnym konsekwencje jurydyczne nie są jedynie uzależnione od decyzji woli danej osoby, lecz są ściśle zdeterminowane przez prawodawcę $e^{34} \mathrm{Z}$ drugiej strony należy dodać,

${ }^{3 n}$ Zob. F. de Castro y Bravo, El negocio jurídico, Madrid 1967, s. 19-35; R, Scognamiglio, Negozio giuridico, w: Enciclopedia giuridica, pod red. G. Treccani, t. 20, s. 1-21.

${ }^{31}$ Zob. A. Trabucchi, Istituzioni di diritto civile, Padova 1993, s. 120: Czytamy tutaj: „I negozi giuridici che sono costituiti da manifestazioni di volontà dirette a ottencre determinati effetti giuridici; nei quali le modificazioni nelle situazioni giuridiche sono direttamente legate alla volontà di chi pone in essere l'atto".

${ }^{32}$ Zob. F. Santoro-Passarelli, Atto giuridico, w: Enciclopedia del diritto, t. 4, Vatese 1959, s. 208: „La differenza tra atto e negozio si coglie dunque in una considerazione complessiva della struttura e della funzione. Il negozio funzionalmente serve a disporre e strutturalmente consiste in una volontà preccetiva; a sua volta l'atto conta non per ciò che cventualmente dispone ma per ciò che è: comportamento umano in cui voluntarietà e consapevolezza rilevano solo come requisito del comportamento medesimo, in quanto gli effetti preordinati dalla legge prescindono dal contenuto volitivo dell'atto.

Di recente abbiamo occasione di affermare che il negozio ha sempre funzione e quindi natura dispositiva. (...) Mentre il negozio ha una costante attitudine a modificare sostanzialmente e autonomamente, nel senso della sua disposizione, la situazione su cui incide, tale attitudine manca ail'atto in senso stretto. (...) In conclusione, il criterio indicato, che si fonda essenzialmente da una parte sul concetto di negozio come autoregolamento impegnativo, dall'altra su quello di atto come comportamento umano, volontario c consapevole, che rileva quale mero presupposto di effetti preordinati rigidamente dalla legge(...)".

${ }^{33}$ Ciprotti, Atto, j.w., s. 214: „Negozi giuridici (...) sono gli atti in cui si concreta l'esercizio di diritti soggetivi”; Michiels, j.w., s. 573; J. Otaduy, Norma y actos jurídicos, w: Manuale de Derecho Canónico, Pamplona 1993, s. 339-341.

${ }^{34}$ Trabucchi, j.w., s. 121: „Gli atti giuridici in senso stretto, che consistono in quegli atti umani leciti, giuridicamente rilevanti, che non sono negozi, pur essendo presupposto di vari effetti giuridici. Pertanto la caratteristica commune ai vari atti di questa categoria è data da ciò: che le conseguenze giuridice non sono stabilite dalla volontà di chi li pone in essere ma sono preordinate dalla legge (podkreślenie autora). La volontà del soggetto viene in considerazione quale presuposto necessario dell'atto umano; è tale comportamento dell'uomo, è non la volontà delle conseguenze, che l'ordinamento valuta per colegarvi i previsti effetti giuridici" 
iż ów effectus iuridicus nie zostałby osiagnięty, jeżeli podmiot nie podjąłby decyzji co do określonego działania ${ }^{35}$. Niektórzy $z$ autorów podkreślają ponadto, iż negotium iuridicum może przybrać postać actus licitus lub actus illictus, natomiast actus iuridicus zawsze będzie aktem legalnym ${ }^{36}$.

\subsection{Inne akty}

Analiza materii kodeksowej wykazuje, iż w sformułowaniu kan. 128 kpk z 1983 r. występuje również termin, ,inny akt" (alius actus). W tym kontekście rodzi się więc pytanie: co należy rozumieć pod tym wyrażeniem? Zdaniem teoretyków prawa idzie o akty ludzkie mające znaczenie praktyczne lub faktyczne, lecz nie pociagające jednak za sobą konsekwencji prawnych ${ }^{37}$. Niektórzy z autorów mówią o ,aktach podobnych do aktów prawnych" (rechtsgeschäftsähnliche Handlung) ${ }^{38}$. Dla zobrazowania mechanizmów działania tej kategorii można by posłużyć się przykładem malarza malującego obraz. Mimo tego, iż jego wysiłek wypływa aktem woli, to jednak nie wywiera on żadnych skutków prawnych.

\section{Analiza semantyczna Kodeksu z 1983 r.}

Dociekania nad treścią kodyfikacji z 1983 r. wykazują, iż w tym tekście legislacyjnym ani razu nie pojawia się termin ,fakt prawny”. Często

${ }^{35}$ Zob. M. Thériault, Introducción, al cc. 124-128, w: Comentario exegético al Código de Derecho Canónico, pod. red. A. Marzoa, J. Mirasa, R, Rodríguez - Ocana, t. 1, Pamplona 1996, s. $821:,(\ldots)$ la ley otorga un efecto jurídico al acto. En efecto, la ley prevé abstractamente que tal acto tendrá tal efecto querido por cl ligislador, pero ese efecto no puede producirse más que si el agente realiza el acto en cucstión".

${ }^{36}$ Zob. E. Calvo Tojo, Error y el dolo en el consentimiento matrimonial según el nuevo Código de Derecho Canónico, w: Curso de drecho matrimonial y porcesal canónico para profesionales del foro, pod red. J. Sanchez y Sanchez, t. 6, Salamanca 1984, s. 120; Romani, j.w., s. 197.

${ }^{37}$ Walser, j.w., s. $16-17$ : „Rechtshandlung ist eine Handlung, deren Rechtswirkung dem Handlungswillen und der Rechtsordnung entspringt, wäherend eine Handlung nicht direkte angestrebte Rechtswirkungen aufgrund von Anordnung des Rechts hervorbringt und deswegen auch "willentliche Rechtstatsache genannt wird".

${ }^{38}$ Heimler, Pree, j.w., s. 102. 
spotykamy natomiast określenie factum ${ }^{39} . \mathrm{Z}$ tych przesłanek nie można jednak wnioskować, iż to zjawisko w kanonistycznym systemie prawnym nie jest obecne. Przykłady bowiem co do istnienia tego fenomenu przedstawiono już wyżej.

Z drugiej strony należy zaznaczyć, iż w legislacji z 1983 r. jedynie trzykrotnie prawodawca użył określenia negotium iuridicum ${ }^{40}$. O wiele częściej natomiast występuje termin „działanie" (negotium) ${ }^{41}$. Warto przy tym zaznaczyć, że ta figura jurydyczna nie występuje w materialnym prawie małżeńskim.

W końcu należy podkreślić, iż najczęstszą kategorią terminologiczną występującą w Kodeksie Jana Pawła II w poruszanej tu materii jest określenie actus iuridicus ${ }^{42}$. Z tym pojęciem spotkamy się nie tylko w tytule VII księgi I, lecz jest ono również obecne w pięciu innych normach ${ }^{43}$.

${ }^{39}$ Zob. X. Ochoa, Index verborum ac locutionum Codicis iuris canonici, Roma 1984, s. 190. Pojçcic to występuje w następujęcych kanonach: kan. 14 kpk z 1983 r., kan. $15 \$ 2$ kpk z 1983 r., kan. 144 kpk z 1983 r., kan. $489 \$ 2$ kpk z 1983 r., kan. 694 \$ 2 kpk z 1983 r., kan. $695 \$ 2$ kpk z 1983 r., kan. 1047 \$ 1 kpk z 1983 r., kan. 1084 \$ 2 kpk z 1983 r., kan. 1212 kpk z 1983 r, kan. 1266 kpk z 1983 r., kan. 1339 \& 2 kpk z 1983 r., kan. 1400 \& 1 n. 1 kpk z 1983 r., kan. 1504 $\S 2$ kpk z 1983 r., kan. 1509 \$ 2 kpk z 1983 r., kan. 1526 \& n. 2 kpk z 1983 r., kan. $1530 \mathrm{kpk}$ z 1983 r., kan. 1531 \$ 2 kpk z 1983 r., kan. 1535 kpk z 1983 r., kan. 1538 kpk z 1983 r., kan. 1574 kpk z 1983 r., kan. 1586 kpk z 1983 r., kan. 1612 \& kpk z 1983 r., kan. $1616 \$ 1$ kpk z 1983 r., kan. 1632 \& 2 kpk z 1983 r., kan. $1645 \$ 2$ n. 2 kpk z 1983 r., kan. 1658 \& 1 n. 1 kpk

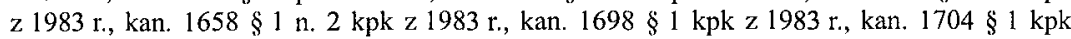
z 1983 r., kan. 1717 \$ 1 kpk z 1983 r,

${ }^{40}$ Tamże, s. 283. Idzic tu o następujące przepisy: kan. 393 kpk z 1983 r., kan. $532 \mathrm{kpk} \mathrm{z} 1983$ r, $543 \$ 2$ n. 3 kpk z 1983 r,

${ }^{41}$ Tamże, s. $282-283$. W następujących przypadkach spotykamy to wyrażenic: kan. $119 \$ 2$ kpk z 1983 r., kan. 127 \$ kpk z 1983 r., kan. 140 \$ 1 kpk z 1983 r., kan. 140 \& kpk z 1983 r., kan. $141 \mathrm{kpk} \mathrm{z} 1983$ r., kan. $238 \S 2$ kpk z 1983 r., kan. $345 \mathrm{kpk}$ z 1983 r, kan. $353 \S 3 \mathrm{kpk}$ z 1983 r., kan. 360 kpk z 1983 r., kan. $365 \$ 2$ kpk z 1983 r., kan. 457 kpk z 1983 r., kan. 473 $\S 1$ kpk z 1983 r., kan. 476 kpk z 1983 r., kan. 479 \& 2 kpk z 1983 r., kan. 480 kpk z 1983 r, kan. $483 \S 1$ kpk z 1983 r., kan. $486 \S 2$ kpk z 1983 r., kan. 495 § 2 kpk z 1983 r., kan. $500 \S 2$ kpk z 1983 r., kan. 506 \& 1 kpk z 1983 r., kan. 595 \$ 1 kpk z 1983 r., kan. 631 \& 1 kpk z 1983 r., kan. $638 § 3$ kpk z 1983 r., kan. $639 \$ 2$ kpk z 1983 r., kan. 708 kpk z 1983 r., kan. 1247 kpk z 1983 r., kan. $1276 \S 2$ kpk z 1983 r, kan. 1295 kpk z 1983 r., kan. 1452 § 1 kpk z 1983 r., kan. $1536 \$ 1$ kpk z 1983 r., kan. 1548 \& 2 n. 1 kpk z 1983 r,

${ }^{42}$ Dla porównania w Kodcksie z $1917 \mathrm{r}$, prawodawca użył pojęcia actus $w$ kan. $11 \mathrm{kpk}$ z 1917 r., kan. 103 - 104 z 1917 r., kan. 1679 kpk z 1917 r., W kan. 1687 \$ 1 kpk z 1917 r, użyto zaś pojęcia negotium.

${ }_{43}$ Ochoa, j.w., s. 9. Autor ten wymienil nastapujące przespisy, a mianowicie: kan. $86 \mathrm{kpk}$ z 1983 r,; kan. $124 \S 1$ kpk z 1983 r., kan. $124 \$ 2$ kpk z 1983 r., kan. 128 kpk z 1983 r., kan. $638 \S 2 \mathrm{kpk} \mathrm{z} 1983 \mathrm{r}$, 
Należy jednocześnie dodać, iż ustawodawca w wielu innych sformułowaniach skorzystał $\mathrm{z}$ terminu actus ${ }^{44}$.

$Z$ przeprowadzonych badań wynika, iż w prawie małżeńskim ani razu nie pojawia się wyrażenie akt prawny. W pięciu jednak normach spotykamy pojęciem aktu (kan: $1057 \S 2 \mathrm{kpk} \mathrm{z} 1983$ r., kan. $1061 \S 1 \mathrm{kpk}$ z 1983 r., kan. 1079 § 3 kpk z 1983 r., kan. $1101 \S 2$ kpk z 1983 r., kan. $1157 \mathrm{kpk}$ z $1983 \mathrm{r}$.,). W tym miejscu należy podkreślić, iż w trzech przepisach określenie to odnosi się z całą pewnością do kategorii actus iuridicus (kan: 1057 \& 2 kpk z 1983 r., kan. 1101 § 2 kpk z 1983 r., kan. 1157 kpk z 1983 r.).

$Z$ drugiej strony należy zauważyć, iż analiza semantyczna materii kodeksowej jest pomocna, lecz niewystarczająca w ocenie mechanizmów jurydycznych regulujących funkcjonowanie kanonistycznego porządku prawnego. W wielu bowiem normach dane zjawisko nie zostaje wprost nazwane przez ustawodawce, a jednak jest ono obecne w przestrzeni tego systemu. Stąd też staramy się uwzględnić zarówno wymiar semantyczny jak i strukturalny norm.

44 Tamże, s. 8-9. Pojęcie to występuje w nastepujących normach, a mianowicic: kan. 10 kpk z 1983 r., kan. 13 § 2 n. 2 kpk z 1983 r., kan. 30 kpk z 1983 r., kan. 37 kpk z 1983 r., kan. 40 kpk z 1983 r., kan. 41 kpk z 1983 r., kan. 43 kpk z 1983 r., kan. 45 kpk z 1983 r., kan. 76 \$ kpk z 1983 r., 124 \& 1 kpk z 1983 r., kan. 126 kpk z 1983 r., kan. 1273 \& 1 kpk z 1983 r., kan. $127 \S 2$ n. 1 kpk z 1983 r., kan. $127 \$ 2$ n. 2 kpk z 1983 r., kan. $135 \$ 2$ kpk z 1983 r., kan. 137 \$ 1 kpk z 1983 r., kan. 137 \& 2 kpk z 1983 r., kan. 137 \$ 3 kpk z 1983 r., kan. 142 \$ 2 kpk z 1983 r., kan. $171 \S 1$ kpk z 1983 r., kan. 353 \& kpk z 1983 r., kan. 382 § 3 kpk z 1983 r., kan. 417 kpk z 1983 r., kan. 505 kpk z 1983 r., kan. 638 \$ kpk z 1983 r., kan. $668 \$ 5$ kpk z 1983 r., kan. 692 kpk z 1983 r., kan. 749 \& 1 kpk z 1983 r., kan. 752 kpk z 1983 r., kan. $834 \$ 2$ kpk z 1983 r., kan. $877 \S 3$ kpk z 1983 r., kan. 904 kpk z 1983 r., kan. 916 kpk z 1983 r., kan. 962 $\S 2$ kpk z 1983 r., kan. 1041 \& 6 kpk z 1983 r., kan: 1057 \& kpk z 1983 r., kan. 1061 \& kpk z 1983 r., kan. $1079 \$ 3$ kpk z 1983 r., kan. $1101 \S 2$ kpk z 1983 r., kan. 1157 kpk z 1983 r., kan. 1201 kpk $\$ 1$ kpk z 1983 r., kan. $1201 \$ 2$ kpk z 1983 r., kan. 1201 \$ 3 kpk z 1983 r., kan. 1210 kpk z 1983 r., kan. 1244 \$ 2 kpk z 1983 r,, kan. 1281 \$ kpk z 1983 r., kan. 1281 \$ 2 kpk z 1983 r., kan. 1283 \& 3 kpk z 1983 r., kan. 1299 \& 1 kpk z 1983 r., kan. 1300 kpk z 1983 r., kan. 1302 \$ 1 kpk z 1983 r., kan. $1323 \$ 4$ kpk z 1983 r., kan. 1328 \$ 2 kpk z 1983 r., kan. 1355 \$ 2 kpk z 1983 r., kan. 1338 \& 2 kpk z 1983 r., kan. 1372 kpk z 1983 r., kan. 1373 kpk z 1983 r., kan. 1387 kpk z 1983 r., kan. 1389 \& 1 kpk z 1983 r., kan. 1389 \$2 kpk z 1983 r., kan. kan. 1405 § 2 kpk z 1983 r., kan. 1418 kpk z 1983 r., kan. 1451 \& 2 kpk z 1983 r., kan. 1466 kpk z 1983 r., kan. 1473 kpk z 1983 r., kan. kan. 1484 \$ 2 kpk z 1983 r., kan. $1503 \$ 2$ kpk z 1983 r., kan. 1524 \& 2 kpk z 1983 r., kan. $1569 \$ 2$ kpk z 1983 r., kan. 1598 \& 1 kpk z 1983 r., kan. 1617 kpk z 1983 r., kan. 1619 kpk z 1983 r, 


\section{Akt prawny a kanoniczne prawo małżeńskie}

Oceniając naturę oraz mechanizmy rządzące normami z zakresu materialnego prawa małżeńskiego (kan. $1055-1165 \mathrm{kpk} \mathrm{z} 1983 \mathrm{r}$.) należy zauważyć, iż w tym obszarze jurydycznym spotykamy jedynie kategorie aktu prawnego $0^{45}$. Taki stan jest w pełni zrozumiały, ponieważ ius matrimoniale jest prawem publicznym. Stąd też nie ma w nim miejsca na autonomię prywatną ${ }^{46}$. Małżeństwo bowiem jest podstawową komórką społeczności jaką, jest Kościół ${ }^{47}$.

Stąd też kontrahent zawierając dany związek małżeński nie czyni tego według własnej woli, lecz z zgodnie z koncepcją tej instytucji ściśle określoną przez prawodawcę kościelnego. Tak więc wolność podmiotów w odniesieniu do instytucji małżeństwa nie jest absolutna. Albowiem mogą oni jedynie podjąć decyzję o małżeństwie oraz wybrać osobę którą chcą poślubić. Nie mogą natomiast decydować o koncepcji małżeństwa, tzn. są bowiem zobowiązani do zawarcia go według woli prawodawcy ${ }^{48}$.

\section{Wnioski}

Zaprezentowana analiza wykazała, iż w obszarze kanonicznego prawa małżeńskiego występuje jedynie kategoria aktu prawnego. Albowiem struktura norm tej dziedziny prawa jest odzwierciedleniem publicznego

\footnotetext{
${ }^{45}$ Jedynie bowiem kategoria małżeństwa zawartego pod warunkiem zdaje się posiadać znamiona dziłania prawnego.

${ }^{46} \mathrm{Na}$ temat tego zagadnienia zob. Fornćs, j.w., s. 78-79.

${ }^{47}$ Zob. O. Robleda, Es contrato el matrimonio?, w: De matrimonio coniectanea, Roma 1970, s. 615 .

${ }^{48}$ Zob. G. Erlebach, Problem wymiaru antropologicznego i prawnego w rozumieniu zgody małżeńskicj, Ius matrimonialc 4: 1999, s. 17. Autor ten stwierdził: „Cechą specyficzną zgody małżeńskicj jako kontraktu jest nie tylko jej przedmiot, ale i określony zespół cech pozostających poza zakresem rozporządzalności kontrahentów. Aby ich konsens powołal do życia prawdziwe (czyli ważne) małżeństwo, musi micć jako przedmiot nic tylko dobro ich samych jako małżonków oraz dobro ewentualnego potomstwa (dwa aspekty esencjalne), ale nie mogą oni wykluczyć pozytywnym aktem woli ich związku małżońskiego"; V. Reina, El consentimiento matrimonial sus anomalias, y vicios como causa de nulidad, Barcelona 1974, s. 34-35. Czytamy tutaj: „Este predominio de la libre voluntad como «causa eficiente» del negocio matrimonial no debe entenderse como libertad contractual en sentido técnico, como si la voluntad de los contrayentes pudiera incidir sobre el contenido del negocio modificándolo en alguna medida. $\mathrm{Al}$ contrario, el contenido del negocio está sutancialmente predeterminato en el ordimaniemto jurídico, y las partes sólo tiene libertad de contracr (clección del estado matrimonial y de la persona con quien instaurarlo)".
} 
charakteru ius matrimonialis. Stąd też w tak pojętym obszarze nie ma miejsca na autonomię prywatną podmiotu.

\section{L'applicazione della categoria dell'atto giudidico nel diritto matrimoniale canonico}

In questo articolo viene presentata la relazione fra la categoria dell'atto giuridico $\mathrm{e}$ il sistema del diritto matrimoniale canonico. L'analisi semantica e strutturale di questa realtà porta alla constatazione che i meccanismi sottostanti al sistema del dirittto matrimoniale canonico possono essere interpretati coerentemente solo sulla base della teoria dell'atto giuridico. Tale interpretazione è rafforzata dal carattere pubblico di questa branca del diritto. 